\title{
Signing Auditor-Specific Characteristics And Audit Report Lag: A Research From Turkey
}

\author{
Murat Ocak, Trakya University, Turkey
}

Evrim Altuk Özden, Trakya University, Turkey

\begin{abstract}
The purpose of this paper is to examine the effect of signing auditor-specific characteristics on the audit report lag using 968 firm-year observations from Borsa Istanbul in the period 2008-2013. The main findings indicate that the gender and education level of signing auditor have a positive effect on audit report lag. Also, big4 audit firms in Turkey encourage auditees to present financial statements timely and they play a substantial role in the reporting. Audit opinion directly affects audit report lag. Firm performance and firm age inversely affect audit report lag. Moreover, big 4's female signing auditors lead to more audit delay. The higher educational level of signing auditors leads to more audit report lag. Signing auditors who hold master's or Ph.D. degrees and also female signing auditors are associated with more audit report lag in firms audited by big4 and non-big4 firms.
\end{abstract}

Keywords: Audit Reporting Lag; Auditor-Specific Characteristics; Big4; Gender; Education Level

\section{INTRODUCTION}

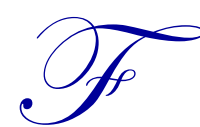

inancial statements should be understandable, reliable, comparable and relevant to provide a true and fair view for decision-making by stakeholders. The timeliness, a component of relevance, is a major qualitative attribute of financial reports. Financial statements should be represented on time due to the predictive and feedback value of the information in financial statements. The Capital Markets Board (SPK-CMB) which is the regulatory board of Turkish listed firms, determines the financial reporting obligations for Turkish listed firms, as well as regulating the timeliness of financial reporting. Before the SPK-CMB- regulation in 2013, annual, separate financial statements should have been presented within 10 weeks starting from the end of the fiscal year. Annual consolidated reports also should be issued within 14 weeks following the end of the fiscal year. After the regulations made in 2013, listed firms are obliged to disclose their annual consolidated reports within 70 days and separate financial reports within 60 days (SPK -CMB-, 2003; SPK-CMB-, 2013).

Greater audit effort leads to higher quality of audit outcomes. Audit quality defines that audit detects and states material misstatements of financial reports efficiently and reduces information asymmetry (Dang, 2004; Salehi \& Kangarlouei, 2010). Higher standards in audit should be related to higher financial reporting quality such as less earnings management practices, less material misstatement, less probability of restatement. (Blankley, Hurtt \& MacGregor, 2014; Dang 2004). Independent audits are performed by audit teams in audit firms. An audit team consists of a sufficient number of auditors and audit is performed under the control and observance of a signing auditor. An auditor who signs audit report is called as signing auditor in Turkey. However, he/she is also called as engagement partner in Turkey and other countries. The signing auditor is authorized to sign audit reports. The signing auditor performs the audit on behalf of an audit firm under his/her responsibility and also directs the audit team (Turkish Public Oversight Board -KGK (POA)- 2012). Signing auditor is responsible for audit planning, direction and supervision of audit team members, establishing an audit strategy, timing of the audit and he/she is in charge of making important decisions in the audit stages (Gul, Wu \& Young, 2013). Gul et al. (2013) indicate that the characteristic of signing auditor in the audit team may affect the audit quality. Nelson and Tan (2005) state that an individual auditor should fulfill multiple tasks to form an overall assurance and attestation. Different attributes of the individual auditor in audit team for example gender, bigN experience, education level, birth cohort etc. influence the outcomes. As 
mentioned above, financial statements should be understandable, reliable, comparable and relevant to provide a true and fair view for decision-making by financial statement users. The timeliness, a component of relevance, is a major qualitative attribute of financial reports. Audit reports should be represented on time due to the predictive and feedback value of the information in financial statements. The characteristics of signing auditor who is a director of audit team, a planner of audit work, may have significant role on performing audit work and present audit reports in timely fashion. His/her characteristics such as experience, educational level and professional certificates obtained and gender, etc. are critical factors for performing audit work and those characteristics may affect the members of audit team, audit quality and especially timeliness of audit report. The study purposes to investigate the effects that the characteristics of the signing auditor has on the audit report lag.

Researches regarding the reporting lag are gathered in several categories. Studies in the first category discuss the effects of audit firm-specific characteristics, for example size of audit firm, audit firm tenure with auditee, audit firm specialization, among other things, on the audit report lag (Ashton, Willingham \& Elliott, 1987; Carslaw \& Kaplan, 1991; Ng \& Tai, 1994; Imam, Ahmed \& Khan, 2001; Ahmed, 2003; Ahmad \& Kamarudin, 2003; Leventis, Weetman \& Caramanis, 2005; Owusu-Ansah \& Leventis, 2006; Lee, Mande \& Son, 2009; Türel, 2010; Lee \& Jahng, 2008; Özkan, Karaibrahimoğlu, Acar \& Öz, 2013; Wan-Hussin \& Bamahros, 2013; Erer \& Cömert, 2014; Dao \& Pham, 2014; Blankley et al. 2014; Whitworth \& Lambert, 2014; Chan, Lou \& Mo, 2016). Studies in the second category focus on the effects of auditee-firm specific characteristics, such as size, leverage, age, industry, complexity and opinion of the audit report, on the timelines of financial reporting (Dyer \& McHugh, 1975; Davies \& Whittred, 1980; Carslaw \& Kaplan, 1991; Owusu-Ansah, 2000; Ahmad \& Kamarudin, 2003; Ismail \& Chandler, 2004; Doğan et al. 2007; Ahmed \& Hossein, 2010; Shukeri \& Nelson, 2011; Abidin \& Ahmad-Zaluki, 2012; Alkhatib \& Marji, 2012; Erer \& Cömert, 2014; Dao \& Pham, 2014; Sakka \& Jarboui, 2015). Recent studies are based on the effects of the components of good governance, such as board, board committees and ownership structure, on the reporting lag (Ishak, Sidek \& Rashid, 2010; Apadore \& Noor, 2013; Mouna \& Anis, 2013; Abernathy, Beyer, Masli \& Stefaniak, 2014; Sultana, Singh \& Van der Zahn, 2014).

Numerous prior studies mentioned above have conducted empirical studies of the impact of characteristics at audit firm level and firm level on audit report delay. Several personal attributes of auditor in audit team at individual level such as education level, gender, experiences, age and etc. are used to test the effects on auditor judgments, audit opinion, audit fees and etc. in Gold, Hunton \& Comaa (2009), Zerni (2012), Karjalainen, Niskanen \& Niskanen (2013), Gul et al. (2013), Sutaryo and Lase (2015), Chiang, Lin \& He (2015), Ernstberger, Koch \& Tan (2015), Hardies, Breesch \& Branson (2016)'s papers.

The paper contributes to the literature on audit report lag in many aspects. First, to our knowledge, the study could be considered as the original paper discussing the effect of the characteristics of signing auditor on audit report lag in Turkey and also emerging markets. Second, signing auditor characteristics have not been previously examined in empirical research which investigate the impacts on audit report lag. The research questions this paper seeks is how auditor-specific characteristics affect the audit report lag. In the study, the signing auditor attributes are identified to evaluate the impact on the audit report lag with controlling audit firm and firm-specific characteristics. Our results are important. First, signing auditor has an important role on the audit reporting. Second, the characteristics of signing auditor such as experience and education, affect the audit process, especially timelines of audit reporting.

The rest of the study is organized as follows. Section 2 introduces institutional structure about Turkish audit environment in sum. The third section describes prior research and the hypotheses. Section 4 outlines sample selection procedure, definition of variables and the model. Section 5 and 6 introduce respectively the estimation results and a brief conclusion.

\section{INSTITUTIONAL BACKGROUND}

Investments of multinational firms in Turkey and international trade revealed the necessity of the audit in Turkey (Gücenme \& Arsoy, 2006). Regulations for independent audit firstly established in 1987 by the Capital Market Law (Sanlı \& Özbirecikli, 2012). According to this law, which was revised in 2012, financial statements of issuers and capital market institutions should be audited by independent audit firms according to the principles determined by the 
CMB (Capital Markets Board) (CMB, 2007). The CMB, a public legal entity, was the authority to set standards regarding both preparation and audit of financial statements for listed firms in Turkey.

Moreover, the Banking Regulation and Supervision Agency (BRSA) was founded to regulate and supervise banking system in Turkey (KGK-POA-, 2015). The BRSA was also authorized to determine the audit firms for banks just as the CMB for publicly held companies (Sanlı \& Özbirecikli, 2012).

In Turkey, besides the CMB and the BRSA, various institutions were authorized for auditing and this situation caused a fragmented structure in the field. Turkish Public Oversight Board (KGK-POA-, 2015) was founded in 2011 to resolve this issue in the field of auditing. The KGK-POA-, 2015. has some duties and responsibilities such as setting accounting and auditing standards that are harmonious with international standards, approving statutory auditors and audit firms and declare them in the Authority's website (KGK-POA-, 2015).

In Turkey, criterion for the entities which are subject to independent audit is specified by Cabinet Decree every financial year. (KGK-POA-, 2015). Criterion is being lessened year by year so that independent audit includes more companies. In a close future not only publicly held companies but also SMEs will be subject to independent audit.

According to the KGK-POA-, 2015, 14.275 independent auditor and 222 audit firms are authorized to audit financial statements in Turkish capital market, banking and insurance sectors. Even if the quantity of independent auditors looks like too much, a very small part of them operates in audit market (KGK-POA-, 2015).

\section{PRIOR RESEARCH AND HYPOTHESES}

The literature consists mainly of the influences of audit firm-specific characteristics, auditor-specific characteristics, and firm-specific characteristics on the reporting lag. Audit firm-specific characteristics not only refer to size, the tenure of audit firm, and the audit switch but also the audit opinion. Firm-specific characteristics affecting audit report lag that are mainly discussed in the literature are size, leverage, age, and performance of the auditee firm. Auditorspecific characteristics affecting the audit report lag in this research are identified based on experience and education level of auditor, auditor gender, and license.

In management literature, gender diversity among board and top management is seen as a major factor to increase financial performance, and to prevent accounting manipulation such as earnings management and creative accounting practices (Carter, Simkins \& Simpson., 2003; Campell \& Minquez-Vera, 2008; Berming \& Frick, 2010). Women are generally more risk averse, have high ethical standards and are more conservative in finance-related matters than men (Gul et al. 2013). From this perspective, women are more willing to complete audit work slowly. They spent more time than male auditors on audit work to make a decision whether financial statements are reported compatible with GAAP or they include fraudulent acts that cause a material misstatement. Because of their risk averse nature, they want to minimize the probability of the existence of financial statement frauds. The first hypothesis is presented.

H1: Auditor gender is directly associated with the audit report lag.

Auditor experience can affect the reporting lag. More experienced auditors are more competent than inexperienced auditors and they may identify problematic situations in financial statements more quickly than less experienced auditors, they may also create an appropriate audit plan to work efficiently and to fulfill the audit work quickly (Bonner \& Lewis, 1990; Francis, 2011; Chi, Myers, Omer \& Xie, 2016). Moreover, more experienced signing auditors have positive effects on the members of the audit team to complete audit work quickly since audit work is divided among team members by the signing auditor and team members rely on the signing auditor's experience. The second hypothesis is presented.

H2: Auditor experience is inversely associated with audit report lag.

Auditor's knowledge and risk preference may be influenced by auditors' educational backgrounds. Auditors who hold a graduate degree tend to be more aggressive (Gul et al. 2013). Higher education level contributes to the auditors' knowledge and professional capabilities. Consequently, educated auditors are less likely to be related to audit failure 
(Ye, Cheng \& Gao, 2014). Sutaryo and Lase (2015) state that auditors with more accounting education should complete the audit on time since financial statements such as balance sheet, income statement and their footnotes are highly relevant to accounting field. They found that holding a graduate degree and a professional certificate in accounting have an inverse effect on the audit delay in Indonesia. The third hypothesis is presented.

H3: Auditor education level is inversely associated with the audit report lag.

In the Turkish context, a signing auditor generally holds either a license for sworn-in public accountancy or a certificate for certified public accountancy. Being a certified public accountant (CPA), he/she holds a bachelor degree, is successful in the proficiency examination after they complete their internship that lasts 3 years with and under the control of a professional accountant. If a CPA after having at least 10 years job experience accomplishes proficiency examinations gain a certificate for for sworn-in certified public accountant (Arkkan \& Toraman, 2007). Sworn-in CPAs are generally specialized in tax auditing services and he/she is familiar with tax audit procedures. Consequently, he/she cannot check independent audit work and he/she could not have sufficient knowledge and experience to fulfill the auditing on time. Unlike the argument of the study presents, as stated in the paper by Sutaryo and Lase (2015), Hutchison and Fleischman (2003) stated that professional certification indicates competency which implies specialized accounting knowledge and adherence to professional standards. Using 127 local government firms in Indonesia in 2012, Sutaryo and Lase (2015) found that the percentage of professional certificates on the auditor team has a negative effect on financial statement lag. Unlike Sutaryo and Lase (2015)'s findings, being a sworn-in CPA is a reason to complete the audit of financial statements slowly, as discussed above. The fourth hypothesis is presented.

H4: The professional certification of the auditor is directly associated with the audit report lag.

To test these hypotheses, several variables that may also influence the audit delay are tested. The control variables of the research are audit firm size, auditor tenure, auditor change, audit opinion, age, leverage, performance and size. And it is also controlled for time, sector and firm.

$\mathrm{Ng}$ and Tai (1994) and Imam et al. (2001) assert that staff resources and experience allow bigN audit firms to more rapidly complete their auditing work. Moreover, bigNs audit large firms and they are low-risk clients (Gul et al. 2013). Larger firms may apply greater pressures on bigN firms (Carslaw \& Kaplan, 1991) which may cause bigN firms to perform their audit work in timelier manner compared with non-bigN firms. Ahmed (2003), Ahmad and Kamarudin (2003), Owusu-Ansah and Leventis (2006), Leventis et al. (2005), Türel (2010), Özkan et al. (2013), and Erer and Cömert (2014) analyzed the bigN audit firm effect on the audit delay. They found that being audited by bigN firms was negatively related to the audit delay.

Recent researches argue that the longer relationship (tenure) between audit firm and auditee adversely affects the audit report lag because spending longer time with clients may allow more information about the client's operations, records, and internal control to be known (Ashton et al. 1987; Lee et al. 2009; Dao \& Pham, 2014). The longer relationship between audit firm and auditee may increase the probability of quick preparation of financial statements (Johnson, 1996; Payne \& Jensen, 2002). Lee et al. (2009) examined the correlation between the audit firm-auditee relationship and the reporting lag, using 18,473 firm-years observations during the period 2000-2005. The results indicate that the longer relationship between audit firm and auditee inversely affects the audit report lag in five of the six years. WanHussin and Bamahros (2013), using Malaysian data, also indicate that audit firm tenure is inversely linked to audit delay. Lee and Jahng (2008) using 8,833 firm-years observations from 1999 to 2005 and Berliana (2015) found no significant influence by the audit firm tenure on the audit report lag. Gul et al. (2013), and Sutaryo and Lase (2015) examined the duration of auditor and client relationship and the audit report lag, their results for the correlation indicated it was statistically significant and negative. Following Gul et al. (2013) and Sutaryo and Lase (2015)'s suggestion, auditor tenure is measured as the duration of the signing auditor and auditee relationship in this study.

Audit firm change refers to increases in the audit report lag because new audit firms require time to understand the accounting practice of the new client (Onwuchekwa, Erah \& Izedonmi, 2012). Whitworth et al (2014) and Chan at al (2016) find that firms with auditor change are positively related to the audit delay. Erer and Cömert (2014) also provide evidence of positive effects in terms of audit firm switch, using 1,224 firm-year observations between 2003-2010 in Borsa Istanbul. They report an adverse link between continuing audit firms and the reporting delay. Ahmed and 
Hossain (2010), and Dibia and Onwuchekwa (2013) found no significant association between audit firm change and the reporting delay. Lai and Cheuk (2005) report that the reporting delay is longer if firms change their audit firm to non-bigN from bigN audit firms. This study used auditor change at individual auditor level, as a proxy. A linear association between auditor change and the audit delay is expected as it mirrors in effect audit firm change on the audit delay because the new auditor spends time to comprehend the reporting process and practice of the new auditee. Qualified audit opinion delays the audit report because audit firms are less willing to issue a qualified opinion. Whittred (1980), Ashton et al. (1987), Carslaw and Kaplan (1991), Bamber, Bamber \& Schoderbeck (1993), and CheAhmed and Abidin (2008), Baldacchino, Grech, Farrugia \& Tabone (2016) analyzed the receipt of a qualified opinion on the audit report lag. They found that qualified opinion is positively associated with the reporting lag. Ashton, Graul \& Newton (1989), Ahmad and Kamarudin (2003), Türel (2010), Lee and Jahng (2008), Shukeri and Nelson (2011), and Erer and Cömert (2014) provide supportive evidence suggesting that unqualified opinion has negative effects on the audit report lag.

Younger firms are less capable in gathering, processing and releasing information than older firms and they have weak internal control systems (Owusu-Ansah, 2000; Dibia \& Onwuchekwa, 2013). This can lead to statement lag in young firms. Owusu-Ansah (2000) and Dibia and Onwuchekwa (2013) stated that the age of firms is a component of reporting lag.

Highly leveraged firms have greater debts than equity and require longer auditing time (Alkhatib \& Marji, 2012). Carslaw and Kaplan (1991) state that the audit of debt is more involved and complicated than the audit of equity, in consequence the audit of debt may be more time consuming than the audit of equity. Recent empirical studies indicate leverage directly affects the audit delay (Carslaw \& Kaplan, 1991; Ahmad \& Kamarudin, 2003; Ahmed \& Hossain, 2010; Alkhatib \& Marji, 2012; Erer \& Cömert, 2014; Dao \& Pham, 2014; Sakka \& Jarboui, 2015).

Reporting lag is shorter at profit-making firms. Firms that experience loss are less likely to report bad news to the user of financial statements. Carslaw and Kaplan (1991), Ahmad and Kamarudin (2003) and Özkan et al. (2013) indicate that the loss has a positive effect on the reporting delay. Moreover, firms that experience profit are possible to release financial reports in a short time (Shukeri and Nelson 2011). Doğan et al. (2007), Ahmed and Hossein (2010) and Abidin and Ahmad-Zaluki (2012); respectively employ ROA and ROE variables as indicators of performance; they found supportive evidence suggesting that performance has negative effects on the audit report lag. Aktaş and Karğın (2011) argue that firms with profit experience are negatively associated with reduced lag in financial reporting.

Carslaw and Kaplan (1991) state that larger firms may put pressure on the auditor to fulfill the audit on time. OwusuAnsah (2000) argues that internal control structures of large firms may be strong. Thus, audit firms spend less time and larger firms release financial statements in a timelier manner. Dyer and McHugh (1975), Davies and Whittred (1980), Carslaw and Kaplan (1991), Owusu-Ansah (2000), Ismail and Chandler (2004), and Sakka and Jarboui (2015) indicate that the firm size adversely affects the audit delay.

According to Bamber et al. (1993), van Hout (2012), if Zmijewski (1984)'s score is higher, firms have bad economic condition and firms have greater risk of bankruptcy. Firms with poor financial conditions and greater risk of bankruptcy lead to higher auditor business risk. Thus, auditors have to make more efforts to complete audit work and it will cause more audit delay. Ahmed (2003) and Tanyi (2011) find no evidence audit report lag and firm's financial condition (Zmijewski (1984)'s score). Bamber et al. (1993), Van Hout (2012) find a direct association between audit report lag and firm's financial vulnerability that Zmijewski (1984)'s financial condition index is used as financial performance indicator.

\section{RESEARCH METHODOLOGY}

The following section explains the sample selection, model specification, descriptive statistics, and correlation matrix.

\subsection{Sample Selection}

Totally 356 firms are listed on Borsa İstanbul as of 31 December 2013. 115 firms are financial institutions such as banks, holdings, insurance firms, leasing and factoring firms, trust firms. 4 firms are mining, natural gas firms and 
construction firms. 5 firms of whole sample are tourism, sport firms. Financial institutions and mining, natural gas firms and agriculture, forestry and fishing firms are excluded because they are subject to different regulations. Tourism, sport firms are eliminated because of having different reporting periods). The remaining sample consists of 237 firms listed on Borsa İstanbul (BIST) as of 31 December 2013. The sample consists of 6 year periods from 2008 to 2013. Total number of observations are 1422 firm-year ( 6 years x 237 firms). 39 firms (39 firms x 6 years= 234 firm-years observations) are excluded because of missing audit characteristics, some control variables. The remaining sample consists of 198 firms listed on Borsa İstanbul as of 31 December 2013. The sample consists of 6 year periods from 2008 to 2013. Total number of observations are 1188 firm-year (6 years x 198 firms). 220 observations are excluded because of missing years. The final sample are 968 firm-year observations over the period 2008-2013. The dataset of this study is unbalanced.

The independent variables that reflect the characteristics of signing auditor were hand-collected from the firm's annual report and the KAP (Public Disclosure Platform) database. In Turkey audit reports are signed by one auditor. The names of signing auditors are provided by the firm's audit report in their annual reports. We matched the names of signing auditors with their own curriculum vitae so as to specify the characteristics of signing auditors, including educational level and experience. The certification information of auditors was obtained from KGK-POA's website (www.kgk.gov.tr). Total number of signing auditors in 2008, 2009, 2010, 2011, 2012, and 2013 (engagement partners) in this paper are respectively $145,149,156,172,170,176$. The detailed information regarding the signing auditors are presented in descriptive statistics. The dependent variables related to the audit report lag were obtained from the firm's annual financial statements. All firm-level control variables were gathered from the firm's annual report, KAP database and the FINNET database, an approved and leading database for Turkish Listed Firms.

\subsection{Model Specification}

To investigate the influence of signing auditor characteristics on the audit report lag, the following model was developed. The dependent variable -ARL- is a count variable in which the observations take only non-negative integer values. The distribution of the variable is over-dispersed and the mean of the variable is less than its variance. To overcome the over-dispersion problem, negative binomial regression was used. Therefore, count data often analyzes incorrectly with ordinary least square, it is estimated the following negative binomial model. ${ }^{\mathrm{i}}$

$$
\begin{aligned}
& A R L_{i t}=\beta_{0}+\beta_{1} G E N_{i t}+\beta_{2} E X P_{i t}+\beta_{3} E D U_{i t}+\beta_{4} C E R_{i t}+\beta_{5} B I G 4_{i t}+\beta_{6} T E N_{i t}+\beta_{7} C H G_{i t} \\
& +\beta_{8} O P N_{i t}+\beta_{9} L n A G E_{i t}+\beta_{10} L E V_{i t}+\beta_{11} R O A_{i t}+\beta_{12} L O S S_{i t}+\beta_{12} L n S I Z E_{i t}+\beta_{13} Z M J S K_{i t} \\
& + \text { TIMEit }+ \text { FIRM }_{i t}+\text { SECTOR }_{i t}+\varepsilon_{i t}
\end{aligned}
$$

Previous studies have used the audit report lag in days following the fiscal year-end until the date of the audit report (ARL). As discussed in Bamber et al. (1993), and Schwartz and Soo (1996), the raw form of reporting lag is utilized in the paper. GEN= 1 if the signing auditor is female, 0 otherwise; EXP is the total experience of signing auditor in accounting \& finance; EDU $=1$ if the signing auditor degree is master or Ph.D., 0 otherwise; and CER=1 if the signing auditor is a sworn-in certified public accountant, 0 otherwise.

The model also includes control variables. Consistent with prior research, BIG4=1 if the brand name of audit firm is Deloitte, KPMG, PwC or Ernst\&Young, 0 otherwise; TEN is the duration of the signing auditor and client relationship; $\mathrm{CHG}=1$ if audit firm changed its signing auditor, 0 otherwise; $\mathrm{OPN}=1$ if firm had qualified audit report, 0 otherwise; firm age (LnAGE) using the natural log of firm age; leverage (LEV) is calculated as the total liabilities to total assets ratio, financial performance (ROA) is the net earnings to total assets ratio; LOSS $=1$ if firm declared loss, 0 otherwise; and, size (LnSIZE) using the natural logarithm of year-end total assets were included, financial vulnerability (ZMJWSK) using Zmijewski's model (1984) is calculated as -4.3-4.5 (the net income/total assets ratio) + 5.7 (the total liabilities/total assets ratio) +0.0004 (the current assets/current liabilities ratio). We also include time indicators to control potential time effects, firm to control firm effects, and sector indicators to control the effects of industry in all regressions. 


\subsection{Descriptive Statistics and Univariate Analysis}

The basic statistics for the whole sample, big4 and non-big4, are presented in Table 1 for the model.

Table 1. Descriptive statistics for whole sample, big4 and non-big4

\begin{tabular}{|c|c|c|c|c|c|c|c|}
\hline Variables & $\begin{array}{c}\text { ALL } \\
\text { Mean } \\
\text { (Std.Dev.) }\end{array}$ & $\begin{array}{c}\text { Minimum } \\
\text { (Maximum) }\end{array}$ & $\begin{array}{c}\text { BIG4 } \\
\text { Mean } \\
\text { (Std.Dev.) }\end{array}$ & $\begin{array}{c}\text { Minimum } \\
\text { (Maximum) }\end{array}$ & $\begin{array}{c}\text { NON-BIG4 } \\
\text { Mean } \\
\text { (Std.Dev.) }\end{array}$ & $\begin{array}{l}\text { Minimum } \\
\text { (Maximum) }\end{array}$ & $\begin{array}{l}\text { Test of } \\
\text { Diff. }\end{array}$ \\
\hline ARL & $\begin{array}{c}73.33 \\
(17.42)\end{array}$ & $\begin{array}{c}19 \\
(146)\end{array}$ & $\begin{array}{c}72.11 \\
(17.06)\end{array}$ & $\begin{array}{c}31 \\
(116)\end{array}$ & $\begin{array}{c}75.08 \\
(17.81)\end{array}$ & $\begin{array}{c}19 \\
(146)\end{array}$ & $2.60^{* * *}$ \\
\hline GEN & $\begin{array}{c}0.14 \\
(0.34)\end{array}$ & $\begin{array}{c}0 \\
(1)\end{array}$ & $\begin{array}{c}0.23 \\
(0.42)\end{array}$ & $\begin{array}{c}0 \\
(1)\end{array}$ & $\begin{array}{c}0.06 \\
(0.25)\end{array}$ & $\begin{array}{c}0 \\
(1)\end{array}$ & $-6.92^{* * *}$ \\
\hline EXP & $\begin{array}{l}20.85 \\
(8.13)\end{array}$ & $\begin{array}{c}10 \\
(53)\end{array}$ & $\begin{array}{l}17.77 \\
(4.63)\end{array}$ & $\begin{array}{c}10 \\
(39)\end{array}$ & $\begin{array}{r}25.21 \\
9.85\end{array}$ & $\begin{array}{c}10 \\
(53)\end{array}$ & $15.70^{* * *}$ \\
\hline EDU & $\begin{array}{c}0.22 \\
(0.41)\end{array}$ & $\begin{array}{c}0 \\
(1)\end{array}$ & $\begin{array}{c}0.17 \\
(0.38)\end{array}$ & $\begin{array}{c}0 \\
(1)\end{array}$ & $\begin{array}{l}0.28 \\
0.45\end{array}$ & $\begin{array}{c}0 \\
(1)\end{array}$ & $3.97^{* * *}$ \\
\hline CER & $\begin{array}{c}0.25 \\
(0.43)\end{array}$ & $\begin{array}{c}0 \\
(1)\end{array}$ & $\begin{array}{c}0.17 \\
(0.38)\end{array}$ & $\begin{array}{c}0 \\
(1)\end{array}$ & $\begin{array}{c}0.61 \\
(0.48)\end{array}$ & $\begin{array}{c}0 \\
(1)\end{array}$ & $30.06^{* * *}$ \\
\hline BIG4 & $\begin{array}{c}0.58 \\
(0.49)\end{array}$ & $\begin{array}{c}0 \\
(1)\end{array}$ & & & & & \\
\hline TEN & $\begin{array}{c}2.61 \\
(2.03)\end{array}$ & $\begin{array}{c}1 \\
(12)\end{array}$ & $\begin{array}{c}2.54 \\
(1.71)\end{array}$ & $\begin{array}{c}1 \\
(10)\end{array}$ & $\begin{array}{l}2.71 \\
2.40\end{array}$ & $\begin{array}{c}1 \\
(12)\end{array}$ & 1.18 \\
\hline $\mathrm{CHG}$ & $\begin{array}{c}0.37 \\
(0.48)\end{array}$ & $\begin{array}{c}0 \\
(1)\end{array}$ & $\begin{array}{c}0.35 \\
(0.47)\end{array}$ & $\begin{array}{c}0 \\
(1)\end{array}$ & $\begin{array}{l}0.41 \\
0.49\end{array}$ & $\begin{array}{c}0 \\
(1)\end{array}$ & $1.82^{*}$ \\
\hline OPN & $\begin{array}{c}0.08 \\
(0.27)\end{array}$ & $\begin{array}{c}0 \\
(1)\end{array}$ & $\begin{array}{c}0.03 \\
(0.19)\end{array}$ & $\begin{array}{c}0 \\
(1)\end{array}$ & $\begin{array}{c}0.14 \\
(0.349)\end{array}$ & $\begin{array}{c}0 \\
(1)\end{array}$ & $5.89^{* * *}$ \\
\hline LnAGE & $\begin{array}{c}3.52-36.43- \\
(0.48)\end{array}$ & $\begin{array}{c}0.69 \\
(4.61)\end{array}$ & $\begin{array}{c}3.63 \\
(0.41)\end{array}$ & $\begin{array}{c}2.19 \\
(4.61)\end{array}$ & $\begin{array}{c}3.36 \\
(0.52)\end{array}$ & $\begin{array}{c}0.69 \\
(4.30)\end{array}$ & $-8.93^{* * *}$ \\
\hline LEV & $\begin{array}{c}0.46 \\
(0.22)\end{array}$ & $\begin{array}{c}0.01 \\
(0.94)\end{array}$ & $\begin{array}{c}0.46 \\
(0.22)\end{array}$ & $\begin{array}{c}0.01 \\
(0.94)\end{array}$ & $\begin{array}{c}0.46 \\
(0.22)\end{array}$ & $\begin{array}{l}0.0319 \\
(0.92)\end{array}$ & -0.01 \\
\hline ROA & $\begin{array}{c}0.02 \\
(0.09)\end{array}$ & $\begin{array}{l}-0.54 \\
(0.53)\end{array}$ & $\begin{array}{c}0.03 \\
(0.09)\end{array}$ & $\begin{array}{l}-0.53 \\
(0.42)\end{array}$ & $\begin{array}{r}0.009 \\
(0.09)\end{array}$ & $\begin{array}{l}-0.54 \\
(0.53)\end{array}$ & $-4.47^{* * *}$ \\
\hline LOSS & $\begin{array}{c}0.39 \\
(0.46)\end{array}$ & $\begin{array}{l}0 \\
1\end{array}$ & $\begin{array}{c}0.25 \\
(0.44)\end{array}$ & $\begin{array}{l}0 \\
1\end{array}$ & $\begin{array}{c}0.38 \\
(0.49)\end{array}$ & $\begin{array}{l}0 \\
1\end{array}$ & $4.19^{* * *}$ \\
\hline LnSIZE & $\begin{array}{l}19.46 \\
(1.52)\end{array}$ & $\begin{array}{c}15.63 \\
(23.83)\end{array}$ & $\begin{array}{l}19.96 \\
(1.47)\end{array}$ & $\begin{array}{c}15.83 \\
(23.83)\end{array}$ & $\begin{array}{l}18.76 \\
(1.30)\end{array}$ & $\begin{array}{c}15.63 \\
(22.36)\end{array}$ & $-13.12^{* * *}$ \\
\hline ZMJWSK & $\begin{array}{c}1.53 \\
(1.20)\end{array}$ & $\begin{array}{l}-1.37 \\
4.73\end{array}$ & $\begin{array}{c}1.48 \\
(1.16)\end{array}$ & $\begin{array}{l}-1.37 \\
4.33\end{array}$ & $\begin{array}{c}1.62 \\
(1.25)\end{array}$ & $\begin{array}{l}-1.31 \\
4.73\end{array}$ & $-1.79^{* *}$ \\
\hline Observation & 968 & & 568 & & 400 & & \\
\hline
\end{tabular}

Std. Dev., standard deviations

Standard deviations and maximum values in parentheses

$* * * \mathrm{p}<0.01,{ }^{* *} \mathrm{p}<0.05,{ }^{*} \mathrm{p}<0.1$

The sample mean value of the variable ARL is 73.33 days. The minimum and maximum values of ARL are respectively 19 and 146 days.

Table 1 shows that the average experience of signing auditors (EXP) is 20.85 years. The minimum and maximum value of experience are respectively 10 and 53 years. Of the signing auditors $22 \%$ and $14 \%$, respectively, have master's or Ph.D. degrees and are female (EDU and GEN) for whole sample. Approximately $25 \%$ of the signing auditors are sworn-in certified public accountants (CER) for whole sample. In terms of control variables, $58 \%$ of the sample observations deal with big4 audit firms (BIG4). Of sample observations, $8 \%$ have a qualified audit opinion (OPN). The signing auditor tenure (TEN) mean is 2.61 for whole sample. Of firms in sample, $37 \%$ changed their signing 
auditors and 30.89\% reported loss (LOSS). The sample indicates that Borsa İstanbul firms have a mean leverage of $46 \%$, a mean ROA of $2 \%$. The average age of sample observations (LnAGE) is approximately 36 (Presented in italics in Table 1). The mean value of Zmijewski's score is 1.53 .

Table 1 also shows descriptive statistics and the mean differences of variables between non-big4 and big4 firms. The mean value for female signing auditors in big4 and non-big4 (GEN) are $23 \%$ and $\% 6$, respectively. The mean values of signing auditor experience (EXP) for big4 and non-big4 are 17.77 and 25.21 respectively. Of the signing auditors, $17 \%$ in big 4 and $28 \%$ in non-big4 have master's or Ph.D. degrees (EDU). These results show that the signing auditors in big4 audit firms are less experienced and less educated compared with the signing auditors in non-big4. The mean values of 'certified' signing auditors in big4 and non-big4 (CER) are $17 \%$ and $61 \%$ respectively. The mean values of firms that reported loss (LOSS) in big4 and non-big4 are $25.70 \%$ and $38.25 \%$ respectively. The results show that nonbig4 audit firms employ less female signing auditors and more signing auditors who are certified (sworn in certified public accountant) than big4 firms. Firms audited by big4 are larger (LnSIZE), more profitable (ROA), and younger (LnAGE) than firms audited by non-big4. Big4 audit firms (mean value of ARL variable is 72.11) completed audit works more quickly than non-big4 firms (mean value of ARL variable is 75.08). The mean value of qualified opinion $(\mathrm{OPN})$ that are issued by non-big4 audit firms is $14 \%$, more than the mean value of qualified opinion (OPN) of $3 \%$ issued by non-big4 audit firms. Non-big4 audit firms issue qualified opinions (OPN) more than big4 audit firms. The mean value of Zmijewski's financial condition index is 1.48 for BIG4 and 1.62 for non-big4.

Table 2. Descriptive statistics regarding the attributes of signing auditors (engagement partners)

\begin{tabular}{|c|c|c|c|c|c|c|c|c|}
\hline Variable & Attributes & 2008 & 2009 & 2010 & 2011 & 2012 & 2013 & Total \\
\hline \multirow{3}{*}{ EDU } & Bachelor's & 112 & 118 & 122 & 127 & 135 & 138 & 752 \\
\hline & Master or Ph.D. & 33 & 31 & 34 & 45 & 35 & 38 & 216 \\
\hline & Total & 145 & 149 & 156 & 172 & 170 & 176 & 968 \\
\hline \multirow{3}{*}{ CER } & CPA & 106 & 106 & 120 & 132 & 129 & 127 & 720 \\
\hline & Sworn-in CPA & 39 & 43 & 36 & 40 & 41 & 49 & 278 \\
\hline & Total & 145 & 149 & 156 & 172 & 170 & 176 & 968 \\
\hline \multirow{3}{*}{ BI4 } & Big4 & 87 & 88 & 94 & 101 & 97 & 101 & 568 \\
\hline & Non-Big4 & 58 & 61 & 62 & 71 & 73 & 75 & 400 \\
\hline & Total & 145 & 149 & 156 & 172 & 170 & 176 & 968 \\
\hline \multirow{3}{*}{ GEN } & Female & 125 & 128 & 127 & 139 & 138 & 150 & 807 \\
\hline & Male & 20 & 21 & 29 & 33 & 32 & 26 & 161 \\
\hline & Total & 145 & 149 & 156 & 172 & 170 & 176 & 968 \\
\hline
\end{tabular}

Table 2 presents the descriptive statistics of signing auditors (Engagement partners at individual level). Total number of signing auditors (engagement partners) in 2008, 2009, 2010, 2011, 2012, and 2013 in this paper are respectively $145,149,156,172,170,176$. The number of female signing auditors in 2008, 2009, 2010, 2011, 2012, 2013 are respectively 20, 21, 29, 33, 32, 26. The number of sworn-in CPA signing auditors in 2008, 2009, 2010, 2011, 2012, 2013 are respectively 39, 43, 36, 40, 41, 49 sworn-in CPA. The number of master's or Ph.D. degrees of signing auditors in 2008, 2009, 2010, 2011, 2012, 2013 are respectively 33, 31, 34, 45, 35, 38. The number of signing auditors are employed in Big4 and 64\% of signing auditors are employed in non-big4.

\subsection{Correlation Matrix}

Table 3 illustrates the correlation coefficients among the variable 'audit report lag', audit firm/auditor-specific characteristics, and firm characteristics by using the Pearson test to check for the presence of collinearity. 
Table 3. Correlation Matrix

\begin{tabular}{|c|c|c|c|c|c|c|c|c|}
\hline & ARL & GEN & EXP & EDU & CER & BIG4 & TEN & CHG \\
\hline ARL & 1 & & & & & & & \\
\hline GEN & -0.01 & 1 & & & & & & \\
\hline EXP & -0.03 & $-0.15^{* * *}$ & 1 & & & & & \\
\hline EDU & $0.05^{*}$ & $-0.14^{* * *}$ & $-0.07^{* *}$ & 1 & & & & \\
\hline CER & 0.04 & $-0.24^{* * *}$ & $0.67^{* * *}$ & -0.01 & 1 & & & \\
\hline BIG4 & $-0.11^{* * *}$ & $0.24^{* * *}$ & $-0.45^{* * *}$ & $-0.10^{* * *}$ & $-0.65^{* * *}$ & 1 & & \\
\hline TEN & -0.008 & $-0.06^{*}$ & $0.08^{* * *}$ & -0.02 & $0.07^{* * *}$ & $-0.05^{* *}$ & 1 & \\
\hline CHG & 0.008 & 0.01 & $0.07^{* *}$ & $-0.05^{*}$ & $0.06^{* *}$ & $-0.04^{*}$ & $-0.61^{* * *}$ & 1 \\
\hline OPN & $0.15^{* * *}$ & $-0.07^{* * *}$ & $0.13^{* * *}$ & $0.08^{* * *}$ & $0.17^{* * *}$ & $-0.25^{* * *}$ & -0.04 & 0.03 \\
\hline LnAGE & $-0.10^{* * *}$ & $0.14^{* * *}$ & $-0.11^{* * *}$ & $-0.07^{* *}$ & $-0.10^{* * *}$ & $0.27^{* * *}$ & 0.0004 & -0.03 \\
\hline LEV & $0.06^{* *}$ & -0.04 & 0.0008 & 0.04 & $-0.06^{* *}$ & -0.006 & -0.04 & 0.03 \\
\hline ROA & $-0.19^{* * *}$ & $0.10^{* * *}$ & $-0.06^{* *}$ & -0.0132 & $-0.10^{* * *}$ & $0.16^{* * *}$ & -0.01 & 0.01 \\
\hline LOSS & $0.13^{* * *}$ & $-0.09^{* * *}$ & $0.11^{* * *}$ & -0.03 & $0.16^{* * *}$ & $-0.16^{* * *}$ & 0.02 & -0.0008 \\
\hline LnSIZE & -0.01 & -0.002 & 0.03 & -0.04 & 0.01 & $0.02^{*}$ & $0.02^{* *}$ & -0.02 \\
\hline ZMJWSK & $-0.09^{* * *}$ & 0.02 & $-0.14^{* * *}$ & 0.04 & $-0.06^{* *}$ & $0.06^{* *}$ & 0.01 & 0.008 \\
\hline
\end{tabular}

\begin{tabular}{|c|c|c|c|c|c|c|c|}
\hline & OPN & LnAGE & LEV & ROA & LOSS & LnSIZE & ZMJWK \\
\hline OPN & 1 & & & & & & \\
\hline LnAGE & -0.04 & 1 & & & & & \\
\hline LEV & $0.06^{*}$ & $-0.07^{* * *}$ & 1 & & & & \\
\hline ROA & $-0.23^{* * *}$ & $0.10^{* * *}$ & $-0.27^{* * *}$ & 1 & & & \\
\hline LOSS & $0.20^{* * *}$ & $-0.08^{* * *}$ & $0.18^{* * *}$ & $-0.62^{* * *}$ & 1 & & \\
\hline LnSIZE & 0.00 & -0.02 & -0.03 & 0.02 & -0.04 & 1 & \\
\hline ZMJWSK & $-0.26^{* * *}$ & -0.003 & $-0.68^{* * *}$ & $0.13^{* * *}$ & $-0.08^{* * *}$ & 0.02 & 1 \\
\hline
\end{tabular}

*** $\mathrm{p}<0.01,{ }^{* *} \mathrm{p}<0.05,{ }^{*} \mathrm{p}<0.1$

The significant and highest coefficient is 0.67 between the signing auditor experience (EXP) and the signing auditor certificate (CER). Correlation coefficients among larger audit firms (BIG4), signing auditor certificate (CER), signing auditor tenure (TEN), and the signing auditor change (CHG) are respectively $-0.65,-0.61$. The correlation coefficient between loss (LOSS) and firm size (LnSIZE) is -0.62 . These results do not represent any concern for multicollineariy. According to Gujarati and Porter (2012), it is only a major problem when correlation coefficients between two variables exceed 0.80 .

Correlation coefficients are respectively $0.02 \% ; 27 \% ; 16 \%$; and $24 \%$, among big audit firm (BIG4) and firm size (LnSIZE); big audit firm (BIG4) and firm age (LnAGE); big audit firm (BIG4) and firm financial performance (ROA); and big audit firm (BIG4) and signing auditor gender (GEN). It is suggested that large, older and profitable firms choose big audit firms to audit financial statements; while big audit firms tend to employ female signing auditors. However, correlation coefficients are respectively $-0.05 \% ;-0.04 \% ;-45 \% ;-10 \%$ and $-65 \%$ among big audit (BIG4) and the signing auditor tenure (TEN); big audit firm (BIG4) and the signing auditor change (CHG); big audit firm (BIG4) and the signing auditor expertise (EXP); big audit firm (BIG4) and the signing auditor education level (EDU); and big audit firm (BIG4) and the signing auditor certificate (CER). These findings show that big audit firms choose to employ less experienced and educated persons. The signing auditors in non big audit firms generally hold the certificate of sworn-in certified public accountant. But the signing auditors in big audit firms generally hold CPA certificates. Moreover, firms rarely change their signing auditors if they work with big audit firms. 


\section{REGRESSION RESULTS}

The following section presents the main results and further analysis results for big4 and non-big4 firms.

\subsection{Main Results}

Table 4 shows the negative binomial regression outcomes obtained from equation (1). The value of the Pseudo $\mathrm{R}^{2}$ is about $1 \%$ ii .

Constant value is positive and highly significant at $\mathrm{p}<0.01$. The chibar ${ }^{2}$ value of likelihood-ratio test of alpha is high and significant. This means that data are not poisson and negative binomial regression is appropriate.

Table 4. Main Regression Results

\begin{tabular}{|c|c|c|}
\hline Variables & Expected Sign & Coef. (Std. Err.) Z Stat. \\
\hline GEN & + & $\begin{array}{c}0.0357^{*} \\
(0.0207) \\
1.81\end{array}$ \\
\hline EXP & - & $\begin{array}{l}-0.00589 \\
(0.00128) \\
-0.46\end{array}$ \\
\hline EDU & - & $\begin{array}{l}0.0482^{* * *} \\
(0.0182) \\
2.65\end{array}$ \\
\hline CER & + & $\begin{array}{l}-0.0216 \\
(0.0292) \\
-0.74\end{array}$ \\
\hline BIG4 & & $\begin{array}{l}-0.0370^{*} \\
(0.0217) \\
-1.71\end{array}$ \\
\hline TEN & & $\begin{array}{l}-0.0075 \\
(0.0048) \\
-1.54\end{array}$ \\
\hline $\mathrm{CHG}$ & & $\begin{array}{l}-0.0101 \\
(0.0196) \\
-0.52\end{array}$ \\
\hline OPN & & $\begin{array}{l}0.0796^{* * *} \\
(0.0272) \\
2.92\end{array}$ \\
\hline LnAGE & & $\begin{array}{l}-0.0444^{* * *} \\
(0.0161) \\
-2.74\end{array}$ \\
\hline LEV & & $\begin{array}{l}-1.09 \\
(4.11) \\
-0.26\end{array}$ \\
\hline ROA & & $\begin{array}{l}-4.49^{* * *} \\
(1.10) \\
-3.99\end{array}$ \\
\hline LOSS & & $\begin{array}{l}0.0033 \\
(0.0206) \\
0.16\end{array}$ \\
\hline LnSIZE & & $\begin{array}{c}4.55^{* * *} \\
(4.53) \\
0.10\end{array}$ \\
\hline ZMJSK & & $\begin{array}{l}-0.0126 \\
(0.0085) \\
-1.49\end{array}$ \\
\hline
\end{tabular}

(Table 4 continued on next page) 
(Table 4 continued)

\begin{tabular}{|c|c|c|}
\hline Variables & Expected Sign & Coef. (Std. Err.) Z Stat \\
\hline Time Dummies & & Included \\
\hline Firm Dummies & & Included \\
\hline Sector Dummies & & Included \\
\hline Constant & & $\begin{array}{c}69.87^{* * *} \\
(9.267) \\
7.54\end{array}$ \\
\hline Pseudo $\mathrm{R}^{2}$ & & 0.0168 \\
\hline $\mathrm{LR} \mathrm{Chi}^{2}$ & & $137.22^{* * *}$ \\
\hline Lnalpha & & $\begin{array}{c}-3.319^{* * *} \\
(0.0634)\end{array}$ \\
\hline LR test of Alpha & & $1258.81^{* * *}$ \\
\hline Observations & & 968 \\
\hline
\end{tabular}

Coef, coefficient; Std. Err., standard errors; Z Stat., Z statistics

Standard errors in parentheses and $Z$ statistics in italics

$* * * \mathrm{p}<0.01, * * \mathrm{p}<0.05, * \mathrm{p}<0.1$

Consistent with the hypothesis 1 that states auditor gender is positively (0.0357) and significantly (1.81) associated with the audit report lag. Thus hypothesis 1 is accepted. From risk averse perspective, they spent more time than male auditors on audit work, want to minimize the probability of the occurrence of fraudulent acts, errors, irregularities in financial statements. Thus, they are more willing to complete audit work slowly.

Consistent with the hypothesis 2 which states auditor experience (EXP) is adversely associated with the audit report lag. The negative $(-0.00589)$ and insignificant $(-0.46)$ coefficient for auditor experience does not supports the hypothesis because of its significance. However, the direction of coefficient indicate that the more time auditors spend in accounting and auditing activities, the more varied knowledge they have. Varied knowledge and experience causes audit work to be completed quickly. The results of this study regarding the auditor experience are not consistent with Payne and Jensen (2002).

The coefficient for the auditor education level (EDU) is positive (0.0482) and significant (2.65). Unlike Sutaryo and Lase's (2015) study, auditor education level is a reason increasing the reporting delay. Thus hypothesis 3 is rejected. The negative and significant correlation coefficient between auditor education level (EDU) and auditor experience (EXP) which means that there is a negative linear relationship between the variables. According to the correlation results, if auditors have master's or Ph.D. degrees, they have less experience than the auditors who do not hold either. Auditors with higher education level (excluding bachelor's degree) do not have enough experience to complete audit work quickly.

No statistical evidence (z score: -0.74 ) is found between professional certification of signing auditor (CER) and reporting lag (ARL) to accept hypothesis 4.

In terms of the control variables, audit firm size negatively $(-0.0370)$ and significantly $(-1.710)$ related to the audit report lag. The result shows that big4 firms complete audit work more quickly than the non-big4 audit firms. The result regarding audit firm size is consistent with Ahmad and Kamarudin (2003), Leventis, et al. (2005), and OwusuAnsah and Leventis (2006) and also supports the studies of Türel (2010), Özkan et al. (2013), and Erer and Cömert (2014) which used Turkish public firms.

Auditor tenure (TEN) is negatively (-0.0075) related to the audit report lag (ARL). As it seen in the correlation matrix, tenured auditors are also sworn-in CPAs. Tenured auditors who are also sworn-in CPAs may cause the result to be as expected but insignificant.

Financial performance (ROA), and firm age (LnAGE) are negatively (respectively -4.41 and -0.0444) and significantly (respectively -3.99 and $-2.74, \mathrm{p}<0.01$ ) related to the reporting lag. This result is also compatible with Dibia and Owuchekha's (2013) result which suggested that older firms are more proficient in gathering, processing and releasing 
information than younger firms; causing a reporting lag for younger firms. The result regarding financial performance (ROA) supports Shukeri and Nelson (2011)'s suggestion that firms with loss experience are likely avoid reporting bad news to their shareholders. Moreover, firms which experience profit are likely to release financial reports in a short time. The coefficient for the auditor change (CHG) has an expected sign $(0.0796)$ but is insignificant $(-0.52)$. These study results regarding auditor change support Ahmed and Hossein's (2010) and Dibia and Onwuchekwa's (2013) results. They identified an insignificant relationship between audit firm change at firm level and the audit report lag. In this study, the change refers to auditor change at individual level not audit firm change as in the studies by Ahmed et al. (2010) and Dibia and Owuchekha (2013), but the findings are insignificant similar to the papers by Ahmed et al. (2010) and Dibia and Owuchekha (2013).

Firm size (LnSIZE), and qualified audit opinion (OPINION) positively (respectively 4.04 and 0.0796 ), respectively insignificantly $(0.90)$ and significantly $(2.92, \mathrm{p}<0.01)$ were associated with the audit report lag. Inconsistent with Carslaw and Kaplan (1991), and Owusu-Ansah (2000), the finding in this paper regarding firm size (LnSIZE) shows that firm size is a reason for reporting lag. This result may be because business complexity in large firms delays the audit report lag. Consistent with Whittred (1980), and Ashton et al. (1987), qualified audit opinion delays the audit report lag since audit firms are less willing to issue a qualified opinion. LEV coefficient is negative (-1.09) but inconsistent with this study's expectation, it is statistically insignificant ( $z$ statistic $=-0.26, p>0.10)$ for the total sample. LOSS coefficient is positive (0.0033) and insignificant ( $\mathrm{z}$ statistic $=0.870, \mathrm{p}>0.10)$. Zmijewski's financial condition index (ZMJWSK) is negatively (-0.012) and insignificantly (-1.49) associated with ARL.

\subsection{Further Analysis for Big4 and Non-Big4}

Table 5 shows the outcomes of negative binomial regression both for big 4 and non-big4. The first column contains the results for non-big4, while the second column contains the results for big4. The values of pseudo $\mathrm{R}^{2}$ are about $1 \%$ for both regressions and the chibar ${ }^{2}$ values of likelihood-ratio test of alpha are high and significant. This means that data are not poisson and negative binomial regression is appropriate.

Table 5. Results for Big4 and Non-big4

\begin{tabular}{|c|c|c|c|}
\hline Variables & Expected Sign & $\begin{array}{c}\text { NON-BIG4 } \\
\text { Coef. (Std. Err.) Z Stat. }\end{array}$ & $\begin{array}{c}\text { BIG4 } \\
\text { Coef.(Std. Err.) Z Stat. }\end{array}$ \\
\hline GEN & + & $\begin{array}{c}0.1124^{* *} \\
(0.0496) \\
2.40\end{array}$ & $\begin{array}{c}0.0258 \\
(0.0235) \\
1.10\end{array}$ \\
\hline EXP & - & $\begin{array}{c}0.0010 \\
(0.0016) \\
0.62\end{array}$ & $\begin{array}{l}-0.0030 \\
(0.0022) \\
-1.37\end{array}$ \\
\hline EDU & - & $\begin{array}{c}0.0511^{*} \\
(0.0272) \\
1.88\end{array}$ & $\begin{array}{l}0.0607^{* *} \\
(0.0260) \\
2.33\end{array}$ \\
\hline CER & + & $\begin{array}{l}-0.0214 \\
(0.0330) \\
-0.65\end{array}$ & $\begin{array}{l}-0.0559 \\
(0.2324) \\
-0.24\end{array}$ \\
\hline TEN & & $\begin{array}{l}-0.0120^{*} \\
(0.0065) \\
-1.84\end{array}$ & $\begin{array}{l}-0.0015 \\
(0.0075) \\
-0.21\end{array}$ \\
\hline $\mathrm{CHG}$ & & $\begin{array}{l}-0.0232 \\
(0.0298) \\
-0.78\end{array}$ & $\begin{array}{l}-0.0085 \\
(0.0266) \\
0.32\end{array}$ \\
\hline OPN & & $\begin{array}{c}0.0689^{*} \\
(0.0337) \\
2.04\end{array}$ & $\begin{array}{c}0.0762 \\
(0.0497) \\
1.53\end{array}$ \\
\hline LnAGE & & $\begin{array}{l}-0.0337 \\
(0.0228) \\
-1.48\end{array}$ & $\begin{array}{l}-0.0598^{* *} \\
(0.0242) \\
-2.47\end{array}$ \\
\hline
\end{tabular}

(Table 5 continued on next page) 
(Table 5 continued)

\begin{tabular}{|c|c|c|c|}
\hline Variables & Expected Sign & $\begin{array}{c}\text { NON-BIG4 } \\
\text { Coef. (Std. Err.) Z Stat. }\end{array}$ & $\begin{array}{c}\text { BIG4 } \\
\text { Coef.(Std. Err.) Z Stat. }\end{array}$ \\
\hline LEV & & $\begin{array}{c}7.81 \\
(6.68) \\
1.17\end{array}$ & $\begin{array}{l}-7.57 \\
(5.27) \\
-1.44\end{array}$ \\
\hline ROA & & $\begin{array}{l}-2.94^{*} \\
(1.76) \\
-1.67\end{array}$ & $\begin{array}{l}-5.40^{* * *} \\
(1.42) \\
-3.81\end{array}$ \\
\hline LOSS & & $\begin{array}{l}0.0003 \\
(0.0312) \\
0.01\end{array}$ & $\begin{array}{l}0.0058 \\
(0.0276) \\
0.21\end{array}$ \\
\hline LnSIZE & & $\begin{array}{l}-7.91 \\
(0.0001) \\
-0.69\end{array}$ & $\begin{array}{c}1.62 \\
(4.86) \\
0.33\end{array}$ \\
\hline ZMJSK & & $\begin{array}{l}-0.0102 \\
(0.0134) \\
-0.77\end{array}$ & $\begin{array}{l}-0.0124 \\
(0.0111) \\
-1.11\end{array}$ \\
\hline Time Dummies & & Included & Included \\
\hline Firm Dummies & & Included & Included \\
\hline Sector Dummies & & Included & Included \\
\hline Constant & & $\begin{array}{c}56.992^{* * *} \\
(14.424) \\
3.95\end{array}$ & $\begin{array}{c}60.819^{* * *} \\
(12.530) \\
5.57\end{array}$ \\
\hline Pseudo $\mathrm{R}^{2}$ & & 0.0168 & 0.01190 \\
\hline $\mathrm{LR} \mathrm{Chi}^{2}$ & & $57.41^{* * *}$ & $90.65^{* * *}$ \\
\hline Lnalpha & & $\begin{array}{c}-3.303 \\
(0.0980)\end{array}$ & $\begin{array}{l}-3.375 \\
(0.0842)\end{array}$ \\
\hline LR test of Alpha & & $539.89^{* * *}$ & $672.13^{* * *}$ \\
\hline Observations & & 400 & 568 \\
\hline
\end{tabular}

Coef, coefficient; Std. Err., standard errors; Z Stat., Z statistics

Standard errors in parentheses and $\mathrm{Z}$ statistics in italics

$* * * \mathrm{p}<0.01,{ }^{* *} \mathrm{p}<0.05,{ }^{*} \mathrm{p}<0.1$

When the sample is split into firms audited by big4 and non-big4; Auditor's education (EDU) level has an important positive (0.0511 and 0.0607) and significant (1.88 and 2.33) effect on the audit report lag for each sub-samples as in the main results. Auditor expertise (EXP) has respectively negative (-0.0030) and positive (0.0010) effect on the audit report lag for auditees by big4 and non-big4, but this is not significant (-1.37 and 0.62). Auditor gender (GEN) has positive (0.0258 and 0.1124) effect on the audit report lag for each sub-samples, but is not significant (1.10) for firms audited by big4. The result indicates that female auditors complete audit works more slowly than male auditors for firms audited by non-big4 firms.

The coefficients for auditor tenure (TEN) are negative $(-0.0015$ and -0.0120$)$ for each sub-samples. But it is insignificant (-0.21) for auditees by big4. Auditor change (CHG) are negative (-0.0085 and -0.0232$)$ for firms audited by Big4 and non-big4, but insignificant. Qualified audit opinion (OPN) is positively ( 0.0762 and 0.0689$)$ associated with the audit report lag for each sub-samples, but this is not significant (1.53) for auditees by big4. Firm age (LnAGE) is negatively (-0.0598 and -0.0337) associated with the audit report lag for each sub-samples. But it is insignificant (1.48) for non-big4 audit firms. Financial leverage (LEV) has negative (-7.57) but insignificant (-1.44) effect on the audit report lag for firms audited by big4 and positive (7.81) but insignificant (1.17) effect on the audit report lag for firms audited by non-big4. Firm performance (ROA) is negatively (-5.40 and -2.97) and significantly (-3.81 and 1.67) associated with the audit report lag for each sub-samples. Firm size (LnSIZE) is respectively positively and negatively (1.62 and -7.91) associated with the audit report lag for each sub-samples, but this is not significant $(0.33$ and -0.69). Zmijewski (1984)'s score (ZMJWSK) is negatively (-0.0124 and -0.0102) and insignificantly (-1.11 and $0.77)$ associated with ARL for each sub-samples. Loss is negatively (-3.81 and -1.67) but insignificantly (0.21 and 0.01) associated with ARL for each sub-samples. 


\section{CONCLUSION}

The study aimed to investigate how signing auditor-specific characteristics, such as gender, experience, certificate, and auditor tenure, affect the reporting lag. The main outcomes show that experience of the signing auditor causes financial statements to be presented in timely manner. However, they also show that a signing auditor who holds master's and Ph.D. degrees is adversely linked to the audit report lag. On the other hand, firms audited by big4 audit firms present financial statements more quickly than firms audited by non-big4 audit firms. The sample is divided into two sub-samples as firms audited by big 4 and non-big 4. Thus, it was determined whether auditor-specific characteristics have impacts on the audit report lag or not. Educational level and experience of signing auditors in big 4 audit firms affects audit report lag positively, as in the main results. Female signing auditors and the educational level of signing auditors increase the audit report lag in non-big4 audit firms.

Firm size and qualified opinion, used in the study as control variables, are significantly and positively associated with the reporting lag, except for firms audited by big4 in both main sample and sub-samples. The control variables of 'firm age and profitability' have positive and statistically significant effects on the audit report lag.

Compared with the archival researches such as Gul et al. (2013)'s paper, this paper covers less observations but presents some remarkable findings on the reporting lag for an emerging country - Turkey-. This archival research is the first original study for Turkey. On the other hand, our findings regarding the effects of signing auditor characteristics on the reporting lag are fresh and considerable. The findings of the research should be considered by audit firms, regulatory agencies in the world and especially in Turkey.

\section{AUTHOR BIOGRAPHIES}

Murat Ocak graduated from İstanbul University, İstanbul, Turkey. He holds Ph.D in Business.

Evrim Altuk Özden graduated from Marmara University, İstanbul, Turkey. She Holds Ph.D in Accounting.

\section{REFERENCES}

Abernathy, J. L., Beyer, B., Masli, A., \& Stefaniak, C. (2014). The association between characteristics audit committee accounting expertise, audit committee chairs, and financial reporting timeliness. Advances in Accounting, Incorporating Advances in International Accounting, 30, 283-297.

Abidin, S., \& Ahmad-Zaluki, N.A. (2012). Proceedings of International Congress on Interdisciplinary Business and Social Science, 873-878: Auditor industry specialism and reporting timeliness.

Ahmad, R. A. A., \& Kamarudin, K.A. (2003). Proceedings of Communication Hawaii International Conference on Business, Hawaii, USA: Audit delay and the timeliness of corporate reporting: Malaysian evidence. Available from: https://www.researchgate.net/publication/242086429_Audit_Delay_and_The_Timeliness_of_Corporate_Reporting_Ma laysian_Evidence, [Accessed 7 March 2016]

Ahmed, A. A. A., \& Hossain, Md. S. (2010). Audit report lag: A study of Bangladeshi listed companies. ASA University Review, $4(2), 49-56$.

Ahmed, K. (2003). The timeliness of corporate reporting: A comparative study of South Asian, Advances in International Accounting, 16, 17-43.

Aktaş, H., \& Karğın, M. (2011). Timeliness of reporting and the quality of financial information. International Research Journal of Finance and Economics, 63, 71-77.

Alkhatib, K., \& Marji, Q. (2012). Audit reports timeliness: Empirical evidence from Jordan. Procedia -Social and Behavioral Sciences, 62, 1342-1349.

Apadore, K., \& Noor, M. M. (2013). Determinants of audit report lag and corporate governance in Malaysia. International Journal of Business and Management, 8(15), 151-163.

Arıkan, Y., \& Toraman, C. (2007). The development of the CPA professional in Turkey. Accounting History Papers, Available from: http://journal.mufad.org/index.php?option=com_content\&view=category\&id=903:muhasebe-tarihibildirileri\&Itemid=149\&layout=default\&lang=en, [Accessed 15 February 2016]

Ashton, R. H., Graul, P. R., \& Newton, J. D. (1989). Audit delay and the timeliness of corporate reporting. Contemporary Accounting Research, 5(2), 657-673.

Ashton, R. H., Willingham, J. J., \& Elliott, R. K. (1987). An empirical analysis of audit delays. Journal of Accounting Research, 25(2), 275-292. 
Baldacchino, P. J., Grech, L., Farrugia, K, \& Tabone, N. (2016). An analysis of audit report lags in Maltese Companies. Contemporary Studies in Economics and Financial Analysis, 98, 161-182.

Bamber, E. M., Bamber, L. S., \& Schoderbeck, M. P. (1993). Audit structure and other determinants of audit report lag: an empirical analysis. Auditing: A Journal of Practise \& Theory, 12(1), 1-23.

Berliana, R. (2015). The effect of workload, auditor tenure, specialist auditor and public accounting firm size on audit reporting lag. Available from: http://papers.ssrn.com/sol3/papers.cfm?abstract_id=2577098, [Accessed 20 March 2016]

Berming, A., \& Frick, B. (2010). Who is the better monitor? The impact of female board directors, board composition, and board size on earnings management. German Economic Association of Business Administration-GEABA- Discussion Paper No.10-18, 1.28. Available from: http://geaba.de/DP/DP-10-18.pdf, [Accessed 25 March 2016]

Blankley, A., Hurtt, D. N., \& MacGregor, J. E. (2014). The relationship between audit report lags and future restatements. Auditing: A Journal Practice \& Theory, 33(2), 27-57.

Bonner, S. E., \& Lewis, B. L. (1990). Determinants of auditor expertise. Studies on Judgement Issues on Accounting and Auditing, 28, 1-20.

Campell, K., \& Minquez-Vera, A. (2008). Gender diversity in the boardroom and firm financial performance. Journal of Business Ethics, 83, 435-451.

Capital Market Board of Turkey (CMB) (2007). Capital market law. Available from: $\mathrm{http}: / /$ www.cmb.gov.tr/displayfile.aspx?action=displayfile \&pageid=64\&fn=64.pdf\&submenuheader=null article 16 and 22, [Accessed 3 December 2016]

Carslaw, C. A. P. N., \& Kaplan, S. E. (1991). An examination of audit delay: Further evidence from New Zealand. Accounting and Business Research, 22(85), 21-32.

Carter, D., Simkins, B. J., \& Simpson, W. G. (2003). Corporate governance, board diversity and firm value. The Financial Review, 38, 33-53.

Chan, K. H., Lou, V. W., \& Mo, P. L. L. (2016). Determinants and implications of long audit reporting lag: Evidence from China. Accounting and Business Research, 46(2), 145-166.

Che-Ahmed, A., \& Abidin, S. (2008). Audit delay of listed companies: A case of Malaysia. International Business Research, 1(4), 32-39.

Chi, W., Myers, L. A., Omer, T. C., \& Xie, H. (2016). The effects of audit partner pre-client and client-specific experience on audit quality and on perceptions of audit quality. Review of Accounting Studies, 1-31.

Chiang, H., Lin, S., \& He, L. (2015). Implications of auditor characteristics and directors' and officers' liability insurance for going-concern audit opinions: Evidence from Taiwan. International Business Research, 8(5), 130-145.

Dang, Li (2004). Assessing actual audit quality. Unpublished Ph.D Thesis, Drexel University.

Dao, M., \& Pham, T. (2014). Audit tenure, auditor specialization and audit report lag. Managerial Auditing Journal, 29(6), 490512.

Davies, B., \& Whittred, G. P. (1980). The association between selected corporate attributes and timeliness in corporate reporting: further analysis. Abacus, 15(1), 48-60.

Dibia, N. O., \& Onwuchekwa, J. C. (2013). An examination of audit reporting lag of companies in the Nigeria stock exchange. International Journal of Business and Social Research, 3(9), 8-16.

Doğan, M., Coskun, E., \& Çelik, O. (2007). Is timing of financial reporting related to financial performance? An examination on ISE listed companies. International Research Journal Finance and Economics, 20, 220-233.

Dyer, J. C., \& McHugh, A. J. (1975). Timeliness of the Australian annual report. Journal of Accounting Research, 13(2), 204219.

Erer, M. \& Cömert, Ç.E. (2014). Timeliness of financial reporting in Turkey. İktisat, Isşletme ve Finans, 29(337), 73-94.

Ernsterberger, J., Koch, C., \& Tan, H. (2015). What dimension of lean auditor expertise matter for audit quality and audit fees? University of Göttingen, Research Seminars. Available from: https://papers.ssrn.com/sol3/papers.cfm?abstract_id=2574639, [Accessed 25 March 2016]

Francis, J. R. (2011). A framework for understanding and researching audit quality. Auditing: A Journal of Practice\& Theory, $30(2), 125-152$.

Gold, A., Hunton, J. E., \& Comaa M. I. (2009). The impact of client and auditor gender on auditors' judgments. Accounting Horizons, 23(1), 1-18.

Gücenme, Ü., \& Arsoy, A. P.(2006). Accounting education in the history of Turkish republic. Mali Çözüm Dergisi, Özel Say1, 74-93.

Gujarati, D. N., \& Porter, D. C. (2012). Basic Econometrics. McGraw-Hill Irvin.

Gul, F.A., Wu, D., \& Yang, Z. (2013). Do individual auditors affect audit quality? Evidence from archival data. Accounting Review, 86(6), 1993-2023.

Hardies, K., Breesch, D. \& Branson, J. (2016). Do (fe)male auditors impair audit quality? Evidence from going-concern opinions. European Accounting Review, 25(1), 7-34. http://www.ats.ucla.edu/stat/stata/output/stata_nbreg_output.htm, [Accessed 01 December 2016]

Hutchison, P. D., \& Fleischman, G. M. (2003). Professional certification opportunities for accountants. The CPA Journal, 73(3), 48-51. 
Imam, S., Ahmed, Z. U., \& Khan, S. H. (2001). Association of audit delay and audit firms' international links: Evidence from Bangladesh. Managerial Auditing Journal, 16(3), 129-133.

Ishak, I., Sidek, A. S. M., \& Rashid, A. A. (2010). The effect of company ownership on the timeliness of financial reporting: empirical evidence from Malaysia. UNITAR E-Journal, 6(2), 20-35.

Ismail, K. N. I. K., \& Chandler, R. (2004). Timeliness of quarterly financial reports of companies in Malaysia. Asian Review of Accounting, 12(1), 1-18.

Johnson, L. E. (1996). Factor influencing municipal audit delay. Accounting Enquiries, 6(1), 121-148.

Karjalainen, J., Niskanen, M., \& Niskanen, J. (2013). American Accounting Association, Annual Meeting 2013 Proceedings: Are female auditors more likely to be independent? Evidence from modified audit opinions.

KGK-POA- (2012). Public oversight, accounting and auditing standards authority. Bağımsız Yönetim Yönetmeliği, Resmi Gazete, Say1:28509, Available from:

http://mevzuat.basbakanlik.gov.tr/Metin.Aspx?MevzuatKod=7.5.16907\&MevzuatIliski=0\&sourceXmlSearch=bağıms1 z, [Accessed 25 March 2016]

KGK-POA- (2015). Public oversight, accounting and auditing standards authority. Available from: https://www.kgk.gov.tr/contents\%5Cfiles\%5CPdf\%5CPublic_Oversight_Authority.pdf, [Accessed 3 December 2016]

KGK-POA-http://www.kgk.gov.tr

Lai, K-W., \& Cheuk, L. M. C. (2005). Audit report lag, audit partner rotation and audit firm rotation: Evidence from Australia. Available from: http://papers.ssrn.com/sol3/papers.cfm?abstract_id=783684, [Accessed 15 March 2016]

Lee, H-Y., \& Jahng G. J. (2008). Determinants of audit report lag: Evidence from Korea- an examination of auditor-related factors. The Journal of Applied Business Research, 24(2), 27-44.

Lee, H-Y., Mande, V., \& Son, M. (2009). Do lengthy auditor tenure and the provision of non-audit services by the external auditor reduce audit report lags? International Journal of Auditing, 13(2), 87-104.

Leventis, S., Weetman, P., \& Caramanis, C. (2005). Determinants of audit report lag: Some evidence from the Athens stock exchange. International Journal of Auditing, 9(1), 45-58.

Mouna, A., \& Anis, J. (2013). Financial reporting delay and corporate governance: Evidence from Tunisia. International Journal of Information, Business and Management, 5(4), 32-46.

Nelson, M., \& Tan, H. (2005). Judgment and decision making research in auditing: A task, person, and interpersonal interaction perspective. Auditing: A Journal of Practice \& Theory, 24, 41-71.

Ng, P. P. H., \& Tai, B. Y. K. (1994). An empirical examination of the determinants of audit delay in Hong Kong. British Accounting Review, 26(1), 43-59.

Onwuchekwa, J. C., Erah, D., \& Izedonmi, F. (2012). Mandatory audit rotation and audit independence: survey of Southern Nigerian. Research Journal of Finance and Accounting, 3(7), 78-85.

Owuso-Ansah, S. (2000). Timeliness of corporate financial reporting in emerging capital markets: empirical evidence from Zimbabwe stock exchange. Accounting and Business Research, 20, 241-254.

Owuso-Ansah, S., \& Leventis, S. (2006). Timeliness of corporate annual financial reporting in Greece. European Accounting Journal, 15(2), 273-287.

Özkan, S., Karaibrahimoğlu, Y. Z., Acar, E. E., \& Öz, İ. O. (2013). Finansal tabloların sunum tarihini etkileyen faktörler: İMKB firmaları üzerine bir uygulama. Muhasebe Bilim Dünyası Dergisi, 15(3), 167-185.

Payne, J. L., \& Jensen, K. L. (2002). An examination of municipal audit delay. Journal of Accounting and Public Policy, 21, 129.

Regression Models with Count Data. Statistical Consulting Group, UCLA Academic Technology Services. Available from http://www.ats.ucla.edu/stat/stata/seminars/count_presentation/count.htm〉, [Accessed 01 December 2016]

Sakka, I. F., \& Jarboui, A. (2015). External auditor's characteristics, corporate governance and audit reporting quality. International Journal of Accounting and Economics Studies, 3(2), 109-116.

Salehi, M., \& Kangarlouei, S. J. (2010). An Investigation of the Effect of Audit Quality on Accruals Reliability of Listed Companies on Tehran Stock Exchange. Review of International Comparative Management, 11(5), 940-960.

Sanlı, N., \& Özbirecikli P. D. (2012). Türkiye'de denetim mesleğinin gelişim süreci: geçmişten geleceğe bir araştırma. Muhasebe ve Denetime Bakış, 38, 1-28.

Schwartz, K. B., \& Soo, B. S. (1996). The Association between auditor changes and reporting lags. Contemporary Accounting Research, 13(1), 353-370.

Shukeri, S. N., \& Nelson, S. P. (2011). Entrepreneurship and Management International Conference (EMIC 2), 1-23: Timeliness annual audit report: Some empirical evidence from Malaysia.

SPK-CMB- (2003). Sermaye Piyasası Kurulu, Seri: XI, No. 25. Sermaye Piyasasında Muhasebe Standartları Hakkında Tebliği, Resmi Gazete, 252, Available from: http://www.spk.gov.tr/apps/teblig/displayteblig.aspx?id=178, [Accessed 30 March 2016]

SPK-CMB- (2013). Sermaye Piyasası Kurulu, Sermaye Piyasasında Finansal Raporlamaya İlişkin Esaslar Tebliği, II-14-1. Resmi Gazete, 28676, Available from: http://www.resmigazete.gov.tr/eskiler/2013/06/20130613-11.htm, [Accessed 30 March 2016]

Stata Annotated Output, Negative Binomial Regression, Available from http://www.ats.ucla.edu/stat/stata/output/stata_nbreg_output.htm [Accessed 01 October 2016]

Copyright by author(s); $\underline{\text { CC-BY }}$ 
Sultana, N., Singh, H., \& Van der Zahn, W. M. (2014). Audit Committee Characteristics and Audit Report Lag. International Journal of Auditing, doi:10.1111/ijau.12033.

Sutaryo, S., \& Lase, Y. (2015). Auditors characteristics and audit delay: Evidence from Indonesian regional governments. Corporate Ownership \& Control, 13(1), 66-73.

Tanyi, P. N. (2011). Essays on audit report lag. Florida International University. FIU electronic thesis and dissertations, Available from: http://digitalcommons.fiu.edu/cgi/viewcontent.cgi?article=1520\&context=etd, [Accessed 15 October 2016]

Türel, A. G. (2010). Timeliness of financial reporting in emerging capital markets: Evidence from Turkey. European Financial and Accounting Journal, 5(1), 113-133.

Van Hout, J. (2012). What determines annual reporting lag for listed companies: Country and company characteristics effects. Tilburg University, Master. Available from: http://arno.uvt.nl/show.cgi?fid=127157, [Accessed 15 October 2016]

Wan-Hussin, W. N., \& Bamahros H. M. (2013). The investment in and sourcing arrangement of the internal audit function affect audit delay. Journal of Contemporary Accounting and Economics, 9, 19-32.

Whittred, G. P. (1980). The timeliness of the Australian annual report: 1972-1977. Journal of Accounting Research, 18(2), 623-6.

Whitworth, J. D., \& Lambert, T. A. (2014). Office-level characteristics of the big4 and audit report timeliness. Auditing: A Journal of Practice \& Theory, 33(3), 129-152.

Ye, K., Cheng, Y., \& Gao, J. (2014). How individual auditor characteristics impact the likelihood of audit failure: Evidence from China. Advances in Accounting, Incorporating Advances in International Accounting, 30, 394-401.

Zerni, M. (2012). Audit partner specialization and audit fees: Some evidence from Sweden. Contemporary Accounting Research, 29(1), 312-340.

Zmijewski, M. E. (1984). Methodogical issues related to the estimation of financial distress prediction models. Journal of Accounting Research, 22, 59-82. 


\section{ENDNOTES}

${ }^{\mathrm{i}}$ Regression Models with Count Data, Statistical Consulting Group, UCLA Academic Technology Services,

http://www.ats.ucla.edu/stat/stata/seminars/count_presentation/count.htm

ii Stata Annotated Output, Negative Binomial Regression, http://www.ats.ucla.edu/stat/stata/output/stata_nbreg_output.htm 